\title{
BLAHÓ JÁNOS - TÓTH JÓZSEF (SZERK.): TANULMÁNYOK MENDÖL TIBOR SZÜLETÉSÉNEK 100. ÉVFORDULÓJÁRA
}

\author{
(A Mendöl Tibor Centenáriumi Év Bizottsága, \\ Orosháza-Pécs, 2006. 133 o.) \\ PETRÁS EDE
}

A 2005. év folyamán emlékezett meg a hazai földrajztudomány Mendöl Tibor születésének századik évfordulójáról. A neves tudós elött tisztelgö, egész évben zajló Békés megyei rendezvénysorozat lezárásaképpen jelent meg ez a tanulmánykötet, melyben a szakma jeles képviselöi idézik meg az 1965-ben elhunyt profeszszor emlékét. Tanulmányaik szervesen kapcsolódnak a Mendöl által hátrahagyott szellemi örökséghez. Egy részük ismerteti a tudós életének és munkásságának egyes aspektusait, míg mások Mendöl valamely eredményéhez vagy ötletéhez kapcsolódva gombolyítják tovább az életmú fonalát.

A kötet elején álló tanulmányban Blahó János a tudós életét és munkásságát mutatja be. Szerzője, aki maga is a Mendölt kinevelö békési evangélikus közösség képviselője, méltán hangsúlyozza a szülöi ház, az alma mater (a szarvasi Evangélikus Gimnázium) és a pezsgő szellemi életü, polgáriasult kisváros jellem- és szellemformáló hatását. Kiemeli az ifjú Mendöl szorgalmát, nem mindennapi rendszerezö képességét és már korán megmutatkozó földrajzi érdeklődését. Képet ad a pályája csúcsán álló tudós szakmai tevékenységéröl, hatalmas munkabírásáról, valamint arról a megalkuvást nem türó föllépéséről, amellyel mindenkor kiállott a tudományos meggyőződése mellett. Az írás fontos, hiánypótló része Mendöl életmüvének teljes bibliográfiája, melyben a mindeddig meg nem jelent kisebb munkák, kiadatlan egyetemi jegyzetek is szerepelnek.

Antal Zoltán tanulmánya részletes képet fest Mendöl Tibor tudományos munkásságáról, összehasonlítva azt a gazdaságföldrajz másik két nagy kortárs hazai mủvelöje, Teleki Pál és Markos György életmủvével. A számos ponton érintkező és sokban egybehangzó életmüvek közül kiemeli azokat a területeket, amelyeken Mendöl lényegesen több vagy mélyebb eredményt ért el. Ezek egyike, hogy pályatársainál jóval nagyobb hangsúlyt fektetett a településszerkezeti kérdésekre, ezen belül is az alföldi települések problematikájára. Érdeklödése egyrészt az Orosházához közeli Nagyszénáson, ill. Szarvason töltött gyermekkorában, másrészt pedig a debreceni egyetemi években gyökerezik, melyek folyamán bensóséges viszonyba került az Alföldre jellemzó sajátos településformákkal - a tanyával és a tanyás mezővárossal. A mendöli életmü másik kiemelkedô pontja a tudós tananyagfejlesztő tevékenysége, melynek nyomán fỏldrajztanáraink többsége máig az ő jegyzeteinek tudásanyagát 
Tér és Társadalom 22. évf. 2008/4. 229-243. p.

és (talán) szellemiségét közvetíti az ifjúság felé. Általános emberföldrajzi jegyzetének legjobban kidolgozott részei a biológiai földrajznak, a mezőgazdasági földrajznak és a tengeri közlekedés földrajzának a leírása, amelyek apropóján árnyalt és érzékletes képet adott a leendő tanárok számára, akiknek nem sok reményük lehetett arra, hogy valaha is személyesen felkeressék a könyvben leírt távoli vidékeket.

Becsei József tanulmányában az alföldi mezővárosok fejlődési útját mutatja be, és ismerteti Mendöl Tibor, Erdei Ferenc és Györffy István téziseit az alföldi városok eredetéről és szerkezetéről. A mezővárosi településszerkezet kialakulását a középkor végi pusztásodási folyamat és a történelmi városfejlődési tendenciák kölcsönhatásából eredezteti, amely a hódoltsági korban a marhaexport konjunktúrája és a földesúri ellenőrzés meggyengülése folytán valódi fellendülést eredményezett. A mezövárosok fejlödését tárgyaló újabb téziseknek (Kubinyi 2000) ellentmondva éles határt von a 14-15. századi polgár- és jobbágy (vagyis mezö-)városok közé.

Csapó Tamás Mendöl 1936-os városmorfológiai írásából kiindulva elemzi az alföldi városok szerkezeti és funkcionális morfológiájában napjainkig bekövetkezett változásokat. Rámutat, hogy a Mendöl által leírt egykori szerkezetükből a kisebb mezővárosok őrizték meg a legtöbbet.

A Mendöl úttörö munkája óta jelentösen gyarapodott hazai szakirodalom és a közelmúltban folytatott empirikus vizsgálatok alapján Tóth József tanulmányában az Alföld településrendszerét vázolja fel. Részletesen elemzi a kilencvenes évektől zajló társadalmi és gazdasági folyamatok hatását, ám paradigmájában megmarad a rendszerezésnek a hetvenes években uralkodóvá vált, a települések központi funkcióit alapul vevő módszerénél.

Alföldi városmorfológiájában Mendöl részletesen írt a korabeli legnagyobb, de még ma is második legnagyobb tanyás városunkról, Kecskemétről. Az életmünek ezen a nyomvonalán indul el Csatári Bálint, aki tanulmányában Kecskemét egykori, 1950-ben elszakított tanyás településeinek fejlődési útját mutatja be. Tézise szerint a valaha létezö tanyás mezövárosi övezet az elmúlt fél évszázad során jelentősen átalakult. Kezdetben az új tanyaközségek meghatározó demográfiai folyamatai a népesség koncentrációja, a távolabbi határrészek elnéptelenedése és az elvándorlás voltak, mára viszont erỏteljes szuburbanizációs tendenciák, a népesség növekedése és egy új külterületi kirajzás figyelhető meg. Csatári második tézise szerint az egykori kecskeméti tanyavilág mezögazdasági jellege - az államszocializmus durva, a mezövárosi-parasztpolgári jelleget megtagadó beavatkozásainak, majd az újkapitalizmus idószakában a mezögazdaság leépülése és a külterületi szabályozás elégtelenségének a következtében - radikálisan csökkent, ezzel párhuzamosan pedig felértékelődött a szuburbanizálódó külterületi övezet lakófunkciója.

Az elmúlt két évtizedben gomba módra szaporodó városi jogállású települések problematikájáról elmélkedik tanulmányában Dövényi Zoltán. A jellemzően alacsony népességü, funkcióikban és városképükben sem igazán városias „kvázivárosok" támasztotta településtudományi anomáliák kezelésére felveti két új településkategória, a törpeváros és a címzetes város bevezetését. Megjegyzésre érdemes, hogy a jogállás szabályozásától jórészt függetlenül zajlik egy ellentétes irányú folyamat is a 
hazai városhálózatban: a hagyományosan alközponti funkciójú kisvárosok anyagi és kulturális kínálatának beszúkülése, ezáltal városiasságának csökkenése. Enyedi szerint ennek oka az igényesebb fogyasztási szokásokkal rendelkezó középosztályi rétegek megnövekedett mobilitása, minek következtében a lakóhelyükhöz közeli, hiányosabb kínálatú kisvárosok helyett mind nagyobb arányban veszik igénybe a távolabb fekvő nagyobb városok, mindenekelött a regionális központok jobb minöségü és változatosabb szolgáltatásait (Enyedi 2000).

Rakonczai János tanulmányában az Alföld életére mind erősebben kiható szárazodási folyamatot tárgyalja. Rámutat, hogy a talajvíz szintjének csökkenése és a vegetációban végbemenő változások az elmúlt néhány évtizedben rendkívüli mértékben felgyorsultak. Mindebböl azt a következtetést vonja le, hogy már a közeli jövőben komolyan átalakulhatnak mind a mezögazdasági tevékenység körülményei, mind a táj jelenlegi arculata.

A kötetet záró tanulmányukban Michalkó Gábor és szerzőtársai Mendöl Tibor földrajzi miliőfogalmából kiindulva kísérlik meg egy elméleti konstrukció kialakítását, mely a turizmusban hasznosított terek turisztikai miliỏjét igyekszik megragadni.

Az egyes tanulmányok áttekintése után ismét az egész kötetre pillantván megállapíthatjuk, hogy - célkitüzésének megfelelően - méltó emléket állít a 100 éve született tudós munkásságának. Színes, ám mégis mértékadó képet fest Mendöl Tibor életmúvéröl, és a sokféle témát és módszert felölelő tanulmányok a maguk módján mind kötödnek szellemi örökségéhez.

\section{Irodalom}

Enyedi Gy. (2000) A magyar településfejlődés integrációs kihívásai az ezredfordulón. - Csontos J.Locsmándi T. (szerk.) Urbanisztika 2000. Akadémiai Kiadó, Budapest. 117-125. o.

Kubinyi A. (2000) Városfejlődés és vásárhálózat a középkori Alföldön és az Alföld szélén. Csongrád Megyei Levéltár, Szeged. 